\title{
Exemplary Youth Leadership Series: Model the Way ${ }^{1}$
}

\author{
Megan Stein²
}

\section{Introduction}

This publication series is designed to outline strategies and experiences to expose youth to and engage them with leadership concepts. In this publication, students will try on aspects of the first practice of exemplary leaders: modeling the way (Kouzes \& Posner, 2018). These quick, low-cost activities can be implemented by Extension professionals working with youth, after-school youth programming, 4-H leaders, FFA advisors, or youth counselors. These activities are best suited for students ages 10-18. However, modifications are included for each of the activities to allow for different group sizes, ages, and abilities of the youth involved.

\section{Model the Way}

Titles are given, but respect is earned. To be an effective leader, one must set and uphold high personal and professional standards. "Model the way" focuses on a leader's ability to articulate their values and set a good example by aligning their actions with their intentions (Kouzes \& Posner, 2018).

The first commitment of this practice has students "clarify values by finding one's voice and affirming shared values" (Kouzes \& Posner, 2018, p. 14). Values are a person's principles or standards of behavior. These can be clarified through self-reflection on what a person holds in high esteem. No values are correct, and each person will have a unique set of values. Once values are identified, they should be used as guiding principles in decision-making. If you look at a goal you are working to achieve as a destination, values inform the path you take to get there. In teams, shared values should be established to solidify expectations of teammates. This can be completed through a conversation of expectations or the establishment of the group's policies.

The second commitment of modeling the way is "[setting] the example by aligning actions with shared values" (Kouzes \& Posner, 2018, p. 14). Leaders are the role models of organizations. With this responsibility, it is pivotal to align your actions to the shared values of your organization. In a leadership position, you are held accountable not only for your actions but also for the actions of your followers. Model the expectations you have for your organization. This includes seeking feedback, asking purposeful questions, and showing proper commitment.

\section{Activities}

\section{Me in a Photo}

Students will identify and share their values.

\section{MATERIALS}
a) Smartphones OR
b) paper and markers/pens

\section{GROUP SIZE}

Any

1. This document is AEC683, one of a series of the Department of Agricultural Education and Communication, UF/IFAS Extension. Original publication date November 2019. Visit the EDIS website at https://edis.ifas.ufl.edu for the currently supported version of this publication.

2. Megan Stein, lecturer, Department of Agricultural Education and Communication; UF/IFAS Extension, Gainesville, FL 32611.

The Institute of Food and Agricultural Sciences (IFAS) is an Equal Opportunity Institution authorized to provide research, educational information and other services only to individuals and institutions that function with non-discrimination with respect to race, creed, color, religion, age, disability, sex, sexual orientation, marital status, national origin, political opinions or affiliations. For more information on obtaining other UF/IFAS Extension publications, contact your county's UF/IFAS Extension office. U.S. Department of Agriculture, UF/IFAS Extension Service, University of Florida, IFAS, Florida A \& M University Cooperative Extension Program, and Boards of County Commissioners Cooperating. Nick T. Place, dean for UF/IFAS Extension. 


\section{INSTRUCTIONS}

1. Have students think of something (object, item, person, activity, event) important to them.

2. Students find a photo on a smartphone that represents that object or item. Alternatively, they can draw the image on a piece of paper.

3. When done, have each student share their image with a partner and explain why it is important to them.

4. Have volunteers share their images with the group.

\section{POTENTIAL WRAP-UP QUESTIONS}

1. Why did you choose that image or picture?

2. Do your friends (club members, fellow camp members, schoolmates) know that thing/object/item is something you find important?

3. Why is it important for others to know what we value?

4. How do you share your values with others?

\section{MODIFICATION}

If students are working together on a team (e.g., officer team, counselor group, club), they could find shared values by finding images that represent what they think is important when working in a team environment. Then discuss how they will hold themselves accountable to these shared values.

\section{Who is the Leader?}

Students will demonstrate the impact of their actions.

\section{MATERIALS}

None

\section{GROUP SIZE}

If there are more than 12 people, have multiple circles, each with a guesser and a leader.

\section{INSTRUCTIONS}

1. Identify one person to be the guesser. Send them out of the room with these instructions: "When you come back into the room, we will be in a circle. One of us will be the leader. The leader will choose the actions everyone else will copy. Your job is to pick the person who is starting and leading each of the movements."
3. Identify one person inside to be the leader. The leader starts a motion (clapping, patting head, waving, etc.).

4. Each individual copies the motions of the leader.

5. The guesser chooses who they think is the leader until they are correct.

${ }^{*}$ Students with potential mobility challenges are able to participate while seated.

\section{POTENTIAL WRAP-UP QUESTIONS}

1. Guesser, why was it hard to identify the leader?

2. Leader, was it challenging having everyone else follow you?

3. Do you think having people copy what we do happens in everyday life?

4. Why do we need to be careful with our actions?

5.How can we ensure that our actions are worth following?

\section{Summary}

Students will engage with the first practice of exemplary leaders, "model the way." Leaders must identify and exemplify values to be effective. These two activities help students illustrate the idea of identifying values and modeling expectations.

\section{Reference}

Kouzes, J. M., \& Posner, B. Z. (2018). The student leadership challenge: Five practices for becoming an exemplary leader. San Francisco, CA: John Wiley \& Sons

2. Have everyone stand in a circle. ${ }^{\star}$ 